\title{
Game Concept for Seual Child Abuse Anticipation
}

\author{
FajarAs'ari \\ Department of Information Systems, Faculty of Computer Science \\ Soegijapranata Catholic University (SCU), Semarang, Indonesia \\ asari.fajar@gmail.com \\ Dr. RidwanSanjaya \\ Department of Information Systems, Faculty of Computer Science \\ Soegijapranata Catholic University (SCU), Semarang, Indonesia \\ ridwan@unika.ac.id \\ FX. HendraPrasetya, ST., MT \\ Department of Information Systems, Faculty of Computer Science \\ Soegijapranata Catholic University (SCU), Semarang, Indonesia \\ hendra@unika.ac.id
}

\begin{abstract}
Sexual child abuse isdirect or indirect action from people who are older than children are.90\% offendersof sexual child abuse are people who are close and known by children. Sexual child abuse preventive measure can be delivered through sexual education by media such as pictures, comic, and video. Creating this media will become a tool to guide parents to teach their children to keep them safe from child sexual abuse.

Parents could choose video that provide animation and stories detailing and watching together with their child, or accompany children and tell story through comic and spending time together. Alternatively, by playing education game, children play it and parents accompany them, explain the story in the game, and enjoy the animation on the game.

This research will discuss about drafting a game as a media to prevent sexual child abuse. Formulating appropriate story for children and information will be presented in the game. Reviewing literature and media that already exist about sexual child abuse and the way to prevent itis materials gathering process. Discussion also has done with psychologist and children's sex education expert to confirm literature review results in order to formulate games for children.
\end{abstract}

Keywords: child sexual abuse, game education, game concept, sex education, game.

\section{INTRODUCTION}

Deviant behavioris an action by individual or group of people that do not fit or not adjust oneself with applicable norms on the society[1]. Many forms of social deviant behaviorare dividedinto two. Based on the level of irregularities divided into primer and secondary irregularities, also based on perpetrators consists of individual and group irregularities [2]. If social deviation do not undergo handling and growing could cause social disease, which of course will have a negative effect on society.

In social disease, crime becomes one of its part. Crime is unlawful acts and norms that exist in society. That is the reasonthe sexual abuseis a crime. Sexual abuse is a discrimination and human right violations that got legal protection in Indonesia and listed in Article 28i paragraph (4) UUD 45. Sexual abuse has comprehensive range, ranging from expressions, verbal, action, showing picture, indecent assault and coercion[3].

Based on interviews withRuhel ${ }^{1}$ or more often called Nona, child sexual abuse consist of physical and psychological. Physical sexual abuse can be described physical contact between victim and offender without victim

\footnotetext{
${ }^{1}$ Ruhel Yabloy, SE. Communication Assistance PILAR PKBI, trainer "You and Me" child sexual abuse prevention method for kinder garden child.
} 
approval and cause victim feel uncomfortable or physical contact that aims to satisfy the sexual desire. Psychological sexual abuse is more in sentence demeaning to children with disrespect words and unusual. Sexual abuse offenders usually are close relative of the child and by physical contact habits on the sensitive area that cause child feel comfortable and without knowing child being the victim of sexual abuse.

Giving basic knowledge about child's private area, and keeping it away from other's touching are hopefully avoiding them from sexual abuse. That information is packed in Underwear Rule. The rules are abbreviated as PANTS[4].In the delivering information process, media has important role. In this case, the media are comic, song, and video. Game application is also part of the media that can distribute information about Underwear Rule to children. A game application could display picture, story, song, and on the top of that video animation in one media. Parents also can participate by explaining some part or information that children hard to understands.

\section{LITERATURE REVIEW 2.1 Child Sexual Abuse}

Sexual abuse in common definition is undesirable sexual behavior through verbal or written, physical, non-verbal, and visual that contain sexual elements or cause anger, insulted, shame, uncomfortable, and insecurity on others [3]. Sexual abuse is a phrase to make it easier to understand sexual violence. It is because sexual abuse has wide definition, including verbal expression (comment, jokes, etc.) that so obscene or indecent, indecent behavior such as pinch, touching, caressing, hugging, etc. Displaying pornographic or indecent images, coercion or indecent acts such as forced to kiss or hug, threatening victim if it does not provide sexual services, even rape.

The victims of sexual abuse are not only adults or teenager, but also children are the target of sexual offenders. Child sexual abuse is classified into indirect and direct sexual contact by adult or people who is older than victim[3].By verbal or word, visual picture, or exposed their private part are indirect sexual action.Including direct sexual action are rape, incest, sexual exploitation by sexual offenders or people who are older than children are.

\subsection{Sex Education}

Sex education is learning about prospective of sexuality, learning about reproduction process - from fertilization till childbirth, sexual values, sexual orientation, body image, decision making, pleasure, dating, communication, relationships, birth control methods, and sexually transmitted infections (STIs) are Kearney assumption[5].Sex education also can be used as an education and leads to good and proper sexual behavior, according to Widjanarko[6].

At an early edge, child should start their sex education programs, Kirby et al thought[5]. The right of every parent to provide knowledge to their children about sexuality when children are ready to take this information, but if only children are asking about sexuality it's really important to take the chance to explain according to child capacity[4]. In a statement that parentsrequire to give children knowledge about sexuality in the playgroup age (3-4 years old), it is supposed to children know the differences or the similarities between male and female then children will know themselves well[6].

\subsubsection{Underwear Rule}

Underwear Rule to keep children from sexual abuse[4]. PANTS abbreviation for rules in Underwear Rule.

- Privates are private;body part covered by underwear is private. People should not ask to see or touch that body part. Even if sometimes doctors, nurse, or family member need to touch that private parts parents should explain it is OK, and people 
should always ask "can I?" first. Moreover, children should know they should not touch or see other people private parts.

- Always remember your body belongs to you, teach children their body belongs to no one, it belongs to them.No one should make children do something with children body that makes uncomfortable feeling.

- No means no, teach children to say no, it is they right to say it. Even to someone they dear or family member. It reminds children that they have control of their body and people respect their feeling.

- Talk about secrets that upset you, it means secret's that makesfeel upset or worried it is should not be secrets, shared and tells your secret that make you feel upset or worried to your parent, adult or teacher you trust. Trouble would never get in to you for telling secret that make you feeling upset and worried.

- Speak up someone can help.Something that makes you upset and worries, talk about it to adult you trust, who will listen to you and able to help. It can be friend's parent, teacher, even Child Line. It does not have to your family member.

\subsection{Video Game andEducation}

\subsubsection{Video Game}

Game has rules when playing the game, to define the goal. On the process to the goal there is challenge with feedback for playing the game, needs interaction, and has a theme[7]. In the 1970s, game often played in video arcade. However, nowadays video game has played on many devices. The devices that support video screen, including cloud computer, game console, mobile phone and other mobile device[8].

\subsubsection{Game Education}

Feels calm or relax and happy when playing a game are the effects of game. Game as a media can be a good media if involving education elements on the game. That makes game could be a media to distribute education to the player. Education could be described as a process to manage attitude to reach the goals by public, group, or individual in the organized way[9].

In the game development process several factors like educational object, topic, achievement, feedback, issue, interaction, redrawn, and story line should be involved, assumedPrensky[10]. The purpose ofInformation distribution on game educationis to enrich knowledge, teaching process support trough interactive media technology[9]. Like history, history could be combined with game to teach and give an experience by being involved on the history story line when playing history game[11].

\section{RESEARCH METHODOLOGY}

\subsection{Literature Review}

Literature review is a collecting data process that exists as a reinforcement theory and resource to formulate the game. Reviewing literature has been done by collecting references from the books, paper, note, etc.[12]. Reviewing literature about child sexual abuse and the ways to prevent it happened to children has been done to create game concept that is supposed to anticipating child sexual abuse.

\subsection{Interview}

Interview method, question answer method to collect data systematically is conducted unilaterally on base of research[12]. Interview can be held in several ways, structured or unstructured, direct or indirect with media communication. A structured interview is an interview when researchers know the required information; otherwise, unstructured interview is when the researcher do not know yet about required information.

Interview withLitaWidyoHastuti, S.Psi.,M.Si ${ }^{2}$ has been done to formulate game

\footnotetext{
${ }^{2}$ Human sexuality and reproductive health psychology
} lecturer Soegijapranata Catholic University (SCU), 
concept for children. Unstructured interview with main issue:

1. How to deliver sex education for children grades 1-3 elementary school? Should sexual organs be displayed, if yes how to display it?

2. Game concept like what does not cause negative impression if children play it?

3. Can the game be published and go public?Can this game be played independently by children?

\section{RESULTS AND DISCUSSION}

\subsection{Results}

Material research process has done with reviewing literature about sex education for children from Underwear Rule and education media such as picture and video.

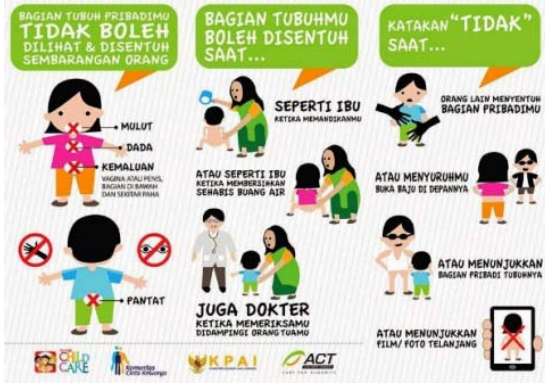

Fig 3. 1 Leaflet Aku Mandiri (AkuMampuMenjagaDiri) www.act.or.id (1)

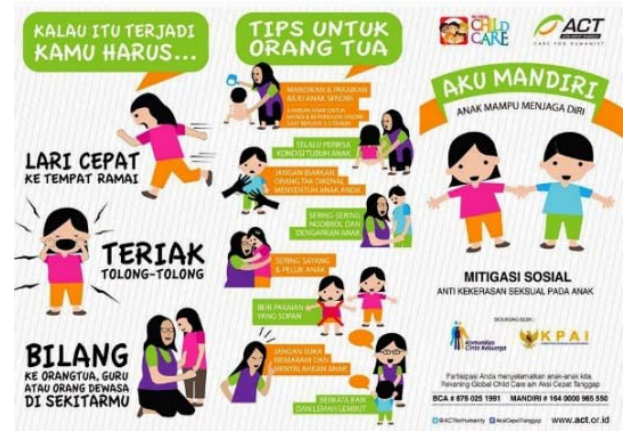

Fig 3. 2 Leaflet “Aku Mandiri” (I Capable Keeping Yourself) www.act.or.id (2)

Semarang, Indonesia. Resource person sex education for children and adolescents. Resource person parenting about development of infantile sexuality.
Fig 3.1 and 3.2 shows child's private parts that should not be touched by others, when that part can be touched, and action should be taken by child when this child get abused.

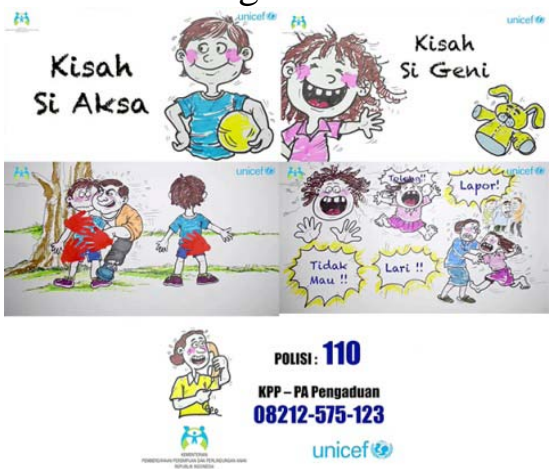

Fig 3. 3 "Kisah Aksa" dan "Kisah Geni"

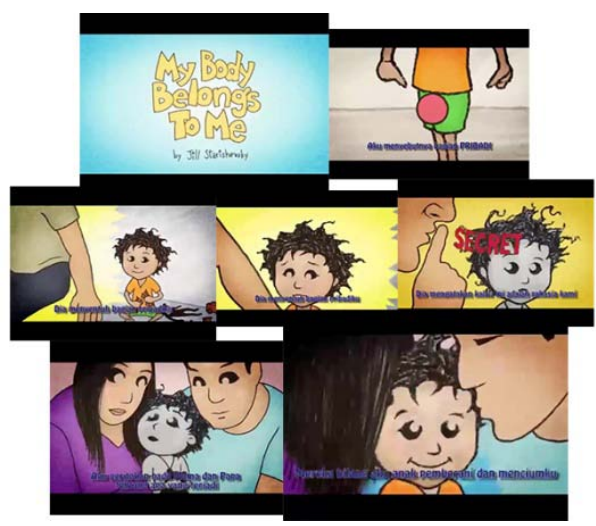

Fig3.4 Socialization Prevention of Sexual Abuse in Children 1

Video captureon Fig 3.3[12, 13] and 3.4[15] are socialization to prevent child sexual abuse by media video and published on YouTube.

In generating game concept for children to anticipate children of being child sexual abuse victims, there are five stages. Stage 1 introduces family members.Stage 2 distinguishes between male and female. Stage 3 till 5 are story simulation when children meet potential offenders with background setting and potential offender in general soit does not refer to someone or just one place.

Information has been added on game to support sex education materials that are delivered through stage 3 till 5 on the game. The common materials on the game stage, in 
the info menu are more focus. For the companion, it is provided a page call about containing summary and explanation of each stage and info on the game.

\subsection{Discussion}

Besides reviewing literature, FajarAs'ari has done interview on Monday, April 11, 2016, and the results are:

1. For elementary school child, especially grades 1-3 they need to introduce again about genitals, don'tthey? If yes,should be introduced by pictures and show explicitly or not?

If talking about the introduction of genitals, it should be known by children when they are at pre-school or kinder garden, so for elementary school there is no need to introduce it again. However, if it is needed, it is more appropriate not to show the genitals explicitly, seeing every different perspective by parents responding this issue. In terms of education, itshould show the genitals explicitly from picture and the way we call it. Therefore, it is better to use picture with fully dressed to shows the part, like around the pants.

2. In the game, how if on the start I give a puzzle about family tree of game characters so that children know which one family or not? Considering sexual abuse, offenders frequently people who are close to children. Previously you should know sex offenders, there are people whom children do not know or stranger, people whom children know but not a family member, and family member itself. Puzzle about family tree I think it is good. In addition,do not forget the place where this crime can happen, it is important to known by children too.

3. From three kind of offenders, does it need to create level for each one, such as one level about stranger case in the park, people whom children know in the school one level too?
If it were made like that probably children will be paranoid in certain place. For example if in the school, after that will direct children even if public in every school has a sex offenders.Therefore, we have tocreate story line that does not refers to someone or certain place. Character, as sex offenders should be created with common name, like fathers friend, avoid direct mention.

4. Back to sexual introduction, so in the game children will guess which one is male and which one is female, is it relevant?

Considering this game for elementary child and they have known how to distinguish male and female, I think it would be good.As long as characters depictions are clearly, the point is if adults cannot describe male or female children are definitely difficult to describe it too.

5. It means if drawn, highlight should be on the body shape to distinguish, is it?

It is.For example from the clothes, male is person who is wearing pants, female who is wearing skirt, or from hairdo that could not be referenced again. Because not only male wearing pants, and female there who had short hair. Therefore, more difference in body shape, such as female has wider hips than male and female has breast. Of course, male has different shape than female, like larger arms, or width shoulder.

6. Back to the sex offenders and the scene. If background setting is public place, how is it? Then for characters, beside character that has negative impression there are also characters that have positive impression. For example, in some game level there are two people, one who has known and has good attitude, and the other one is the sex offenders who has known too, how about it Mam?

That is more acceptable, but in the end of the game, thereshould be an explanation wherever the scenesare - place where sexual abuse happen, anyone who can be sex offenders. Therefore,these explanations 
are from general to specific. However, do not forget to give information to children when child's private parts can be touched, when examined by doctor but parents should accompany children.

7. Could this game be published to public or not?

Yes, it could. However, accompanying children is necessary because it is still related to sex education that everyone not familiar with the topic. Therefore, if children play this game, someone should accompany them or this game could be a media for teacher to teach children about sex education.

Research of data resulting in the basic of game conceptfor elementary children, grades $1-3$, with materials are:

1. Child's private partsthat should not be touched by others and what has to do when someone deliberately touch that part.

2. When children meet people who they do not know or people who they know give them snack, gift, or toys. In addition, what has to do when asked to go by stranger?

3. What has to do when children given gift, toys, or snack by someone who is known and parent around them or not.

4. Place where sexual abuse could happen, people who can be the sex offenders, and to whom children can tell they problems and asking for help when they being abuse.

5. The time when child's private parts can be touched, people who can touch it and examples of safe touch for children.

Summary of all materials in simulation story with character and scene generally set not to refer to someone or certain place.

\section{CONSLUSION}

There are five stages on the game to prevent child sexual abuse. Stage one drawing up a family tree, educating children to know which family members and which not family members. Stage two, distinguishing male and female, to recall children ability to distinguish male and female by appearance. Stage three, simulation when child's private parts get touched and ask children to keep it as a secret, however in this stage teach children to share the secret to parent and directing children to share their problems. Stage 4 and 5 tell when children meet people who are unknown or stranger. Educating children to say NO and asking help if they get abuse.

Not only the 5 stage, 3 info has added to support game material and increase children knowledge. First info about child's private parts that should not be touched by other. From mouth, chest, and around the pants or skirt.Second, info about places where child sexual abuse could happen.Such as around the house, school, and public place. Beside places, also explain about people who are known or not by children, who should not force them to do something they do not like. The third information explains the time when child's private part can be touched, such as when children are examined by doctor of course, there are parents who accompany. In the third information also contains kind of safe touch for children.

\section{ACKNOWLEDGEMENT}

FajarAs'ari is the Game Technology student, SoegijapranataChatolic University. Based on academic excellency, he recieves scholarship from Ministry of National Education of Republic

(BeasiswaUnggulanKemendikbud RI)

\section{REFERENCES}

[1] V. Leonad, "Contoh Penyimpangan Sosial Di Lingkungan Masyarakat," academia.edu. [Online]. Available: https://www.academia.edu/8329558/Co ntoh_Penyimpangan_Sosial_Di_Lingku ngan_Masyarakat. [Accessed: 10-Apr2015].

[2] D. Ameilia, "Penyimpangan Tingkah 
Laku dan Kenakalan Remaja,” academia.edu. [Online]. Available: https://www.academia.edu/9136661/Pen yimpangan_Tingkah_Laku_dan_Kenaka lan_Remaja. [Accessed: 21-Apr-2015].

[3] D. V. R. Purwardini, "Kekerasan dan Pelecehan Seksual pada Anak," academia.edu, 2014. [Online]. Available: https://www.academia.edu/8271437/Ma kalah_Ilmu_Sosial_Budaya_Dasar. [Accessed: 10-Apr-2015].

[4] NSPCC, "Simple Conversations to Keep Your Child Safe From Abuse.”

[Online]. Available:

http://www.nspcc.org.uk/preventingabuse/keeping-children-safe/underwearrule/. [Accessed: 10-Apr-2015].

[5] C. Chaiwongroj, K. Buaraphan, and P. Supasetsiri, “Teachers', Students’ And Parents' Perspectives On Sex Education Integrated Curriculum For Sixth Grade Students,” Int. Conf. Multidiscip. Trends Acad. Res., pp. 231-235, 2014.

[6] D. A. Fajar, Susanto, and R. Achmadi, "Strategi Optimalisasi Peran Pendidikan Seks Usia Dini di Paud Dalam Menanggulangi Pelecehan Seks Terhadap Anak di Pekalongan,” J. LITBANG, vol. 13, pp. 40-52, 2014.

[7] A. DeSmet, R. Shegog, D. Van Ryckeghem, G. Crombez, and I. De Bourdeaudhuij, “A Systematic Review and Meta-analysis Involving Serious Digital Games,” J. GAMES Heal., vol. 4, no. 2, pp. 1-13, 2015.

[8] L. Botturi and C. S. Loh, Games : Purpose and Potential in Education, 1st ed. USA, New York: Springer Publishing Company, Inc., 2008.

[9] V. W. Febriani, D. S. Ardityo, and R. Sanjaya, "Idea Development on Games of Education for School's Entrepreneurship Sustainability,” J. Int. Conf. eLearning Knowledge-Based Soc., vol. 19, no. 11, 2014.

[10] H.-Y. Sung, G.-J. Hwang, and Y.-F.
Yen, “Computers \& Education Development of a contextual decisionmaking game for improving students ' learning performance in a health education course,” Comput. Educ., vol. 82, pp. 179-190, 2015.

[11] N. A. Wijaya and R. Sanjaya, "History Lesson using Game as the Tool," Int. J. Comput. Internet Manajement, vol. 19, no. 9, p. 6, 2012.

[12] N. Muhajir and A. H. Bakker, Metode Penelitian. Yogyakarta: Rake Sarasia, 1996.

[13] UNICEF, “Kisah Aksa,” YouTube, 2014. [Online]. Available: https://www.youtube.com/watch?v=zAk EXUbjtKY. [Accessed: 19-Jun-2016].

[14] UNICEF, “Kisah Geni,” YouTube, 2014. [Online]. Available: https://www.youtube.com/watch?v=5e M1U6PXyZk. [Accessed: 19-Jun-2016].

[15] J. Franer, "Sosialisasi Pencegahan Pelecehan Seksual Pada Anak," YouTube, 2013. [Online]. Available: https://www.youtube.com/watch?v=C2 EVb32GadA. [Accessed: 16-Jun-2016]. 